\title{
THE PROPERTIES OF CEMENT MORTAR WITH NATURALZEOLITE AND SILICA FUME ADDITIONS
}

\section{WŁAŚCIWOŚCI ZAPRAWY CEMENTOWE Z DODATKIEM ZEOLITU NATURALNEGO I PYKU KRZEMIONKOWEGO}

DOI: $10.30540 /$ sae-2018-010

\begin{abstract}
This article reports the results of a study evaluating the effect of natural zeolite and silica fume on the properties of cement mortar. The study used binders in which $20 \%$ of portland cement was replaced with the pozzolanic admixtures. Both admixtures were studied separately and combined as a 1:1 blend. Reference samples were produced with non-modified cement binders. The tests were conducted for hydration kinetics on cement pastes, consistencies and strength in flexure and compression on mortars. The results indicated that different pozzolans affected the mortar differently. The effect of zeolite and silica fume blend on the properties of mortars is not an averaged effect of those admixtures used individually.
\end{abstract}

Keywords: Mortar, Pozzolans, Silica Fume, Zeolite

Streszczenie

Niniejsze opracowanie dotyczy wptywu zeolitu naturalnego i pylu krzemionkowego na właściwości zaprawy cementowej. $W$ tym celu sporzadzono spoiwa, w których $20 \%$ cementu portlandzkiego zastępowano dodatkami pucolanowymi. Oba dodatki przebadano oddzielnie, jak i łącznie w formie mieszanki pucolan $w$ stosunku 1:1. Próbki odniesienia wykonano $z$ niemodyfikowanego spoiwa cementowego. Wykonano badania kinetyki hydratacji na zaczynach oraz konsystencji, jak również wytrzymałości na zginanie i ściskanie na zaprawach. Wyniki badań wykazaly, że wplyw różnych rodzajów pucolan na właściwości zaprawy jest odmienny. Wpływ mieszanki zeolitu i pyłu krzemionkowego na właściwości zaprawy nie jest uśrednionym wpływem, jaki wywieraja te dodatki stosowane oddzielnie.

Słowa kluczowe: zaprawa, pucolana, pył krzemionkowy, zeolit

\section{INTRODUCTION}

Mineral admixtures commonly used for the production of cement and concrete are classified into chemically inert materials - fillers, and those which react chemically in the cement paste environment, producing cement composites with modified properties [1-21]. The latter type includes pozzolanic materials.

Pozzolans are a broad group of materials comprising both natural and synthetic types. Synthetic materials with pozzolanic properties include fly ash and silica fume [1-12]. Pumice, metakaolin, opal and zeolites are natural pozzolans [2, 13-23].

Pozzolans have an ability to enter into pozzolanic reaction, that is, to produce calcium silicate hydrates

\section{WPROWADZENIE}

Dodatki mineralne są obecnie powszechnie stosowane w produkcji cementu i betonu. Wśród nich wyróżnia się zarówno dodatki inertne chemicznie - wypełniacze, jak i takie, które w środowisku zaczynu cementowego wchodzą w reakcje chemiczne, na skutek których uzyskiwane są kompozyty cementowe o zmodyfikowanych właściwościach [1-21]. Do dodatków drugiego rodzaju zalicza się materiały wykazujące właściwości pucolanowe.

Pucolany stanowią szeroką grupę materiałów, pośród których wyróżnić można pucolany pochodzenia naturalnego oraz syntetyczne. Do materiałów sztucznych, posiadających właściwości pucolanowe, zalicza się popioły lotne i pył krzemionkowy [1-12]. 
(C-S-H) from the reaction with $\mathrm{Ca}(\mathrm{OH})_{2}[2-4,13]$. The progress of pozzolanic reaction depends on the form of silica, content of amorphous phase and its structure, and specific surface area of the pozzolan $[5,6,15,24]$. The higher the specific surface area is, the faster chemical reactions are due to increased contact area $[3,5,17,24]$. Considering the development of the specific area, special attention should be paid to volcanic ash, calcined clays (tras), metakaolin, silica fume and zeolites [3, 13-17].

Produced by arc electric furnaces during the production of silicon or ferrosilicon alloys, silica fume is characterized by high specific surface area due to very fine spherical particles made mostly of amorphous silica (> 85\%). Considering rheology and reinforcement protection in concrete, it is recommended not to use more than $10 \%$ of silica as cement replacement $[1,3,4,7]$.

Zeolites, which are components of volcanic tuffs, are aluminosilicates with a characteristic loose structure in which cage-like cavities and channels [25] can be distinguished, responsible for the significant nanoporosity of these materials. Because of their porosity, they may exhibit high surface area for pozzolanic reaction to occur. This is due to the dissolution of zeolites in a strongly alkaline environment, whereby silicon ions become available for reaction $[4,18,25]$. Cement can be replaced by zeolite up to $40 \%$ [18-20]. Higher zeolite fraction contributes to a significant deterioration of consistency and strength parameters [18-21]. It may also reduce concrete durability [19]. According to Ahmadi and Shekarchi [18], the use of zeolite in the amount of up to $10 \%$ by cement-zeolite binder mass may, however, result in a more gas-tight microstructure than with the use of silica fume.

Cement and concrete are often produced with only one of the known mineral admixtures. It is also possible to use a blend of several admixtures in one binder. Attention should be paid to the characteristics of these materials that may impair the properties of the fresh and hardened mortar [4, 7]. For zeolites used with other mineral admixtures, the results of studies of blends of zeolite and fly ash or granulated blast furnace slag [22] are reported in the literature. Silica fume used together with fly ash improves fly ash concrete properties [26, 27].

This article reports the effect of addition of natural zeolite and silica fume, used both separately and in the form of a mixture, on the properties of cement mortar.
Wśród pucolan naturalnych można wymienić pumeks, metakaolin, opal i zeolity [2, 13-23].

Pucolany to materiały zdolne do wchodzenia w reakcję pucolanową, czyli wytwarzania uwodnionych krzemianów wapnia (fazy C-S-H) na skutek reakcji $\mathrm{z} \mathrm{Ca}(\mathrm{OH})_{2}[2-4,13]$. Przebieg tej reakcji uzależniony jest od składu chemicznego, formy występowania krzemionki, zawartości fazy amorficznej i jej struktury oraz od powierzchni właściwej pucolany $[5,6,15$, 24]. Im większa jest powierzchnia właściwa materiału, tym reakcje chemiczne mogą zachodzić szybciej, gdyż większa jest powierzchnia kontaktu [3, 5, 17, 24]. Pod względem rozwinięcia powierzchni właściwej, na szczególną uwagę zasługują takie materiały pucolanowe, jak pyły wulkaniczne, prażone gliny (tras), metakaolin oraz pył krzemionkowy i zeolity [3, 13-17].

Powstający w piecach łukowych podczas produkcji krzemu lub stopów żelazokrzemowych pył krzemionkowy cechuje się dużą powierzchnią właściwą, ponieważ składa się z bardzo drobnych, kulistych cząstek. Zbudowane są one przede wszystkim $(>85 \%)$ $\mathrm{z}$ amorficznej krzemionki. Ze względu na właściwości reologiczne i ochronę zbrojenia w betonie niezalecane jest stosowanie tego dodatku mineralnego do cementu w ilości przekraczającej 10\% [1, 3, 4, 7].

Zeolity będące składnikami tufów wulkanicznych są glinokrzemianami o charakterystycznej luźnej strukturze, w której wyróżnić można komory i kanały [25] odpowiedzialne za znaczną nanoporowatość tych materiałów. Ze względu na porowatość mogą one wykazywać duże rozwinięcie powierzchni, na której dochodzi do reakcji pucolanowej. Następuje ona na skutek rozpuszczania się zeolitów w silnie zasadowym środowisku, dzięki czemu jony krzemotlenowe stają się dostępne dla reakcji $[4,18,25]$. Cement może być zastępowany przez zeolit w ilości do 40\% [18-20]. Wyższy udział zeolitu przyczynia się do znacznego pogorszenia konsystencji i parametrów wytrzymałości [18-21]. Może też być przyczyną obniżonej trwałości betonu [19]. Według Ahmadi i Shekarchi [18] stosowanie zeolitu w ilości do $10 \%$ masy spoiwa cementowo-zeolitowego skutkować może jednak uzyskaniem bardziej gazoszczelnej mikrostruktury niż podczas stosowania pyłu krzemionkowego.

Do produkcji cementów i betonów często wykorzystuje się tylko jeden ze znanych dodatków mineralnych. Możliwe jest też wykorzystanie w jednym spoiwie mieszaniny kilku dodatków. Podczas wprowadzania mieszaniny dodatków należy zwracać uwagę na te ich cechy, które mogą pogorszyć właściwości świeżej i stwardniałej zaprawy $[4,7]$. W odniesieniu 


\section{MATERIALS AND METHODS}

Cement CEM I 42.5R, Transcarpathian zeolite and silica fume, with chemical compositions as in Table 1, were used in this study. Transcarpathian zeolite, mined in the Transcarpathian region of western Ukraine $[28,29]$, is an aleurite-psammite vitrocrystalloclastic tuff, zeoliticized due to the interaction of lowtemperature hydrothermal solutions. It contains up to $84 \%$ clinoptilolite by weight, accompanied by volcanic glass [23, 25, 28, 29]. Quartz, plagioclase and biotite make up the remaining $16 \%$. All of the above materials were sieved through a $0.063 \mathrm{~mm}$ sieve prior to application, and the pozzolans were examined for particle size distribution with a laser diffractometer.

Table 2 compiles the composition of binders made from the materials above. The binders were mixed with water to obtain the pastes for evaluating the progress of hydration. Consistency and strength in flexure and compression were determined on mortars. The pastes and mortars were made with water-binder ratio, $\mathrm{w} / \mathrm{b}=0.5$.

Table 1. Chemical compositions of cement and pozzolans [\%]

Tabela 1. Sklad chemiczny cementu i pucolan [\%]

\begin{tabular}{|l|c|c|c|c|c|c|c|c|c|c|c|c|}
\hline Material & $\mathrm{SiO}_{2}$ & $\mathrm{Al}_{2} \mathrm{O}_{3}$ & $\mathrm{Fe}_{2} \mathrm{O}_{3}$ & $\mathrm{Ca} 0$ & $\mathrm{MgO}$ & $\mathrm{SO}_{3}$ & $\mathrm{~K}_{2} \mathrm{O}$ & $\mathrm{Na}_{2} \mathrm{O}$ & $\mathrm{Cl}$ & $\mathrm{TiO}_{2}$ & $\mathrm{MnO}$ & $\mathrm{P}_{2} \mathrm{O}_{5}$ \\
\hline Cement & 18.66 & 5.43 & 2.96 & 62.00 & 1.46 & 3.21 & 0.95 & 0.20 & 0.07 & - & - & - \\
\hline Zeolite & 67.07 & 12.40 & 0.90 & 2.09 & 0.72 & - & 2.80 & 2.05 & - & 0.19 & 0.04 & 0.014 \\
\hline Silica Fume & 93.77 & 2.36 & 1.42 & 0.30 & 0.84 & 0.20 & 1.11 & - & - & - & - & - \\
\hline
\end{tabular}

\begin{tabular}{|l|c|c|c|}
\hline Binder & $\begin{array}{c}\text { Cement CEM I } \\
42.5 R\end{array}$ & $\begin{array}{c}\text { Transcarpathian } \\
\text { Zeolite }\end{array}$ & Silica Fume \\
\hline C & 100 & 0 & 0 \\
\hline CZ & 80 & 20 & 0 \\
\hline CSF & 80 & 0 & 20 \\
\hline CZSF & 80 & 10 & 10 \\
\hline
\end{tabular}

The hydration kinetics was studied by semiadiabatic calorimetry [3]. For this purpose, $5 \mathrm{~g}$ of the binder sample was placed in plastic bags to which $2.5 \mathrm{ml}$ of distilled water was injected. The bags were then placed in a calorimeter, where the heat released from the hydrating binder was monitored for 45 hours.

The consistency was tested in accordance with PNEN 1015-3 [30].

Strength tests have been performed in accordance with PN-EN 196-1 [31]. The samples were prepared in the form of $40 \times 40 \times 160 \mathrm{~mm}$ bars which, after demoulding, were stored in water at $20^{\circ} \mathrm{C}$. Flexure and compressive strength tests were performed after 2 and 28 days of curing. Three bars were made for each type of mortar. do zeolitów stosowanych z innymi dodatkami mineralnymi, można znaleźć wyniki badań nad mieszankami zeolitu i popiołu lotnego albo granulowanego żużla wielkopiecowego [22]. Pył krzemionkowy stosowany wraz z pyłem lotnym poprawia z kolei właściwości betonu popiołowego [26, 27].

$\mathrm{W}$ prezentowanej pracy przedstawiono wpływ dodatku zeolitu naturalnego i pyłu krzemionkowego, stosowanych zarówno oddzielnie, jak i w formie mieszanki na właściwości zaprawy cementowej.

\section{MATERIAŁY I METODY BADAŃ}

W badaniach zastosowano cement portlandzki CEM I 42,5R, zeolit zakarpacki i pył krzemionkowy o składach chemicznych podanych w tabeli 1 . Zeolit zakarpacki to zeolit wydobywany na obszarze Zakarpacia położonego na zachodzie Ukrainy [28, 29]. Jest to zeolityzowany, wskutek oddziaływania niskotemperaturowych roztworów hydrotermalnych aleurytowo-psamitowy, tuf witro-krystaloklastyczny. Zawiera on w swym składzie do $84 \%$ masy klinoptilolit, któremu towarzyszy szkliwo wulkaniczne [23, 25, 28, 29].
Table 2. Composition of binders in pastes and mortars [weight \%]

Tabela 2. Sklad spoiw w zaczynach i zaprawach [\% masy]

Pozostałe $16 \%$ stanowią kwarc, plagioklazy i biotyt. Wszystkie powyższe materiały przed zastosowaniem przesiano przez sito $0,063 \mathrm{~mm}$, a pucolany przebadano pod względem rozkładu uziarnienia dyfraktometrem laserowym.

Z tych materiałów wytworzono spoiwa o składzie przedstawionym w tabeli 2 . Spoiwa zarabiano wodą aby otrzymać zaczyny do badania postępu hydratacji. Dla zapraw określono konsystencję oraz wytrzymałości na zginanie i ściskanie. Zaczyny i zaprawy sporządzono z zachowaniem współczynnika wodno-spoiwowego $\mathrm{w} / \mathrm{s}=0,5$.

Badanie kinetyki hydratacji przeprowadzono metodą kalorymetrii semiadiabatycznej [3]. W tym celu $5 \mathrm{~g}$ 


\section{RESULTS}

The particle size distribution of the zeolite and silica fume used in the tests (Fig. 1) are similar. Zeolite has slightly more $0-25 \mu \mathrm{m}$ particles. Silica fume has less uniform particle size distribution than zeolite, as evidenced by the presence of a hump in the $3-20 \mu \mathrm{m}$ range. Both materials have the particle size ranging from 0 to $100 \mu \mathrm{m}$. The presence of particles above 63 $\mu \mathrm{m}$ despite screening can be explained by aggregation.

The calorimetric curves (Fig. 2, Table 3) indicate that the pozzolanic materials used affect the kinetics of cement hydration. The additives both reduced and accelerated the occurrence of maximum of the main peak in the hydration heat release rate curve. This thermal effect is due to hydration of alite and tricalcium aluminate [32].

In the case of the CSF binder pastes, a distinct third hump peak between $17 \mathrm{~h}$ and $32 \mathrm{~h}$ of hydration is seen. Similar but significantly less prominent humps can be observed for the other two pozzolanic binders. As for silica fume, this thermal effect can be generated by silicon-rich calcium silicates formed as a result of pozzolanic reaction being initiated $[3,33]$. In the zeolite case, the additional thermal effect is due to hydration of the aluminum component [3, 17, 33, 34].
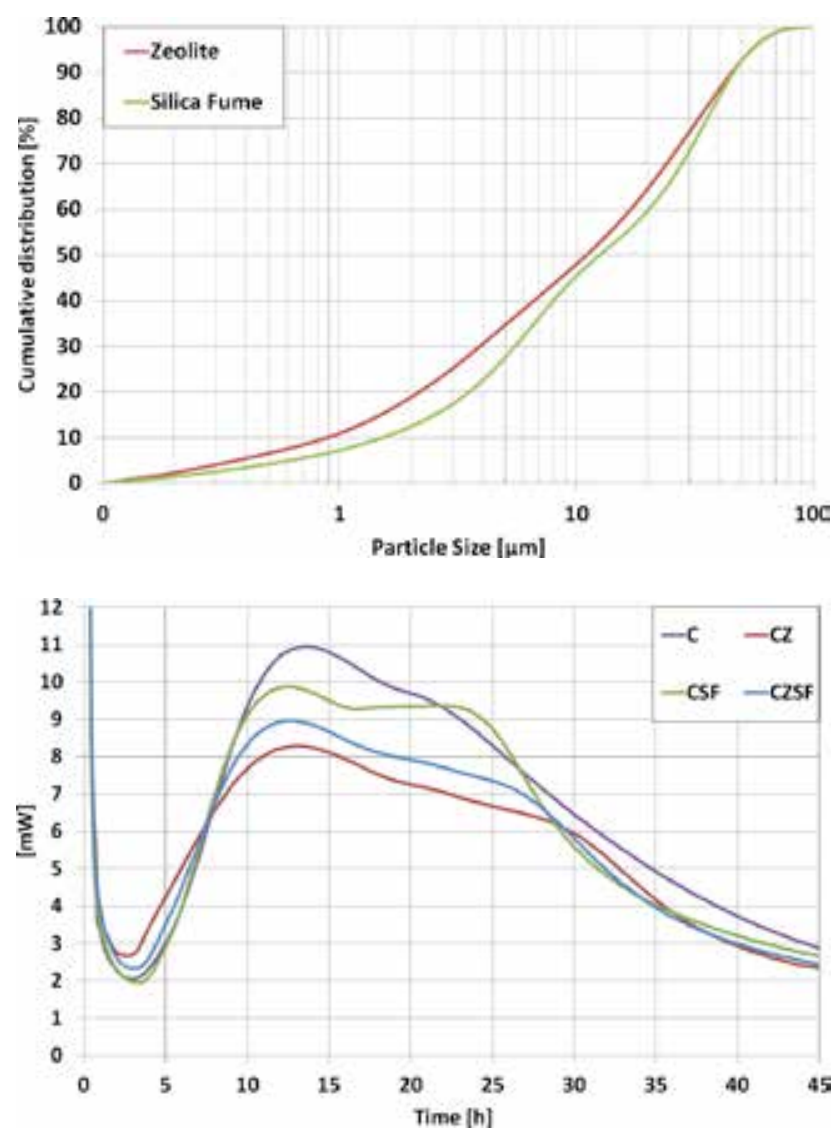

próbki spoiwa były umieszczane w woreczkach foliowych, do których wstrzykiwano 2,5 ml wody destylowanej. Następnie woreczek z próbką umieszczano w kalorymetrze, w którym śledzono wydzielanie się ciepła z hydratyzującego spoiwa przez okres 45 godzin.

Konsystencja została zbadana zgodnie z wytycznymi normy PN-EN 1015-3 [30].

Badania wytrzymałościowe zostały wykonane zgodnie z normą PN-EN 196-1 [31]. W tym celu przygotowano próbki w formie beleczek o wymiarach $40 \times 40 \times 160 \mathrm{~mm}$, które po rozformowaniu dojrzewały w wodzie o temperaturze $20^{\circ} \mathrm{C}$. Badania wytrzymałości na zginanie i ściskanie zostały przeprowadzone po 2 oraz 28 dniach dojrzewania. Dla każdego rodzaju zaprawy wykonano po trzy beleczki.

\section{WYNIKI BADAŃ}

Uziarnienie zastosowanego zeolitu i pyłu krzemionkowego (rys. 1.) jest zbliżone. Zeolit posiada nieco więcej ziaren frakcji 0-25 $\mu \mathrm{m}$. Pył krzemionkowy posiada mniej równomierne uziarnienie niż zeolit, o czym świadczy występowanie na krzywej uziarnienia garbu w zakresie 3-20 $\mu \mathrm{m}$. W przypadku obu dodatków ich uziarnienie mieści się w przedziale $0-100 \mu \mathrm{m}$. Obecność ziaren powyżej $63 \mu \mathrm{m}$, mimo wcześniejszego przesiania przez sito, można tłumaczyć agregacją.

$\mathrm{Na}$ podstawie krzywych kalorymetrycznych (rys. 2, tab. 3) można stwierdzić, że zastosowane dodatki pucolanowe wpływają na kinetykę hydratacji cementu. Wszystkie zastosowane dodatki spowodowały zarówno obniżenie, jak i przyspieszenie wystąpienia maksimum głównego piku na krzywej szybkości wydzielania ciepła hydratacji. Ten efekt termiczny wyni-

\section{Fig. 1. Particle size distribution of pozzolans} Rys. 1. Uziarnienie pucolan

Fig. 2. The heat evolution curves of pastes, $d Q / d t=f(t)$ (notation as in Table 2)

Rys. 2. Krzywe wydzielania ciepła zaczynów, $d Q / d t=f(t)$ (oznaczenia próbek jak w tabeli 2) 


\begin{tabular}{|l|c|c|c|c|}
\hline Binder & C & CZ & CSF & CZSF \\
\hline End of induction period & 225 & 200 & 245 & 220 \\
\hline Maximum of main peak & 825 & 775 & 755 & 755 \\
\hline Hump maximum & - & 1800 & 1450 & 1600 \\
\hline
\end{tabular}

A relationship was observed between the type of pozzolanic admixture and the main peak reduction and period after which the additional thermal effect was generated. These reductions and periods were the smallest for silica fume and the largest for zeolite.

As a result of the use of zeolite additive, the induction period in the $\mathrm{dQ} / \mathrm{dt}=\mathrm{f}(\mathrm{t})$ curve was shorter, decreasing with the increasing content of zeolite. In addition, the zeolite addition was found to contribute to greater heat release at this hydration stage. Silica fume extended the induction period.

Results of the mortar consistency tests, shown in Figure 3, indicate that the applied mineral additives reduced the flow of the mortar. The largest, 23\% flow reduction was recorded for silica fume. By using zeolite alone or by replacing half of silica fume amount with zeolite, a larger flow was obtained. The reduction in the flow for these additives was 19 and $18 \%$, respectively.

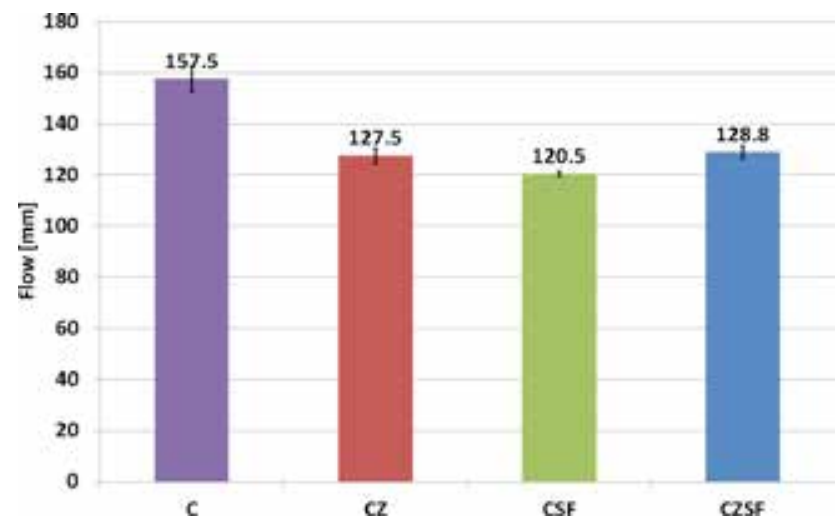

Figures 4 and 5 show the strength parameters of the mortars. These results indicate that the use of pozzolanic admixtures reduced early flexure and compression strengths. The highest reduction was observed in mortars containing only the zeolite addition. The findings from the tests performed after 28 days were also least favourable for the mortar with this binder.
Table 3. Comparison of times [min] of changes in pastes (notation as in Table 2)

Tabela 3. Porównanie czasów zachodzenia przemian w zaczynach [min] (oznaczenia próbek zgodne z tabela 2)

ka z hydratacji alitu i glinianu trójwapniowego [32]. W przypadku zaczynu ze spoiwem CSF widoczny jest wyraźny trzeci pik w postaci garbu między 17 a 32 godziną hydratacji. W przypadku pozostałych dwóch spoiw z dodatkami pucolanowymi występują podobne, ale znaczne mniej wyraźne garby. Odnosząc się do pyłu krzemionkowego, ten efekt cieplny może powstawać wskutek tworzenia się bogatych w krzem krzemianów wapnia w wyniku zapoczątkowania reakcji pucolanowej $[3,33]$. W przypadku zeolitu dodatkowy efekt cieplny jest skutkiem uwadniania składnika glinowego $[3,17,33,34]$.

Zauważyć tu można związek między rodzajem dodatku pucolanowego a obniżeniem głównego piku i okresem, po którym powstaje dodatkowy efekt cieplny. W przypadku zastosowania pyłu krzemionkowego są one najmniejsze, a w przypadku zeolitu największe.

Zaobserwowano też, że na skutek zastosowania dodatku zeolitu tzw. okres indukcji na krzywej dQ/ $\mathrm{dt}=\mathrm{f}(\mathrm{t})$ uległ skróceniu i był tym krótszy, im spoiwo zawierało większą ilość zeolitu. Ponadto stwierdzono, że dodatek zeolitu przyczynił się do większego wydzielanie ciepła na tym etapie hydratacji. W przypadku pyłu krzemionkowego stwierdzono wydłużenie okresu indukcji.

Fig. 3. Consistency of mortars (notation as in Table 2)

Rys. 3. Konsystencja zapraw (oznaczenia próbek jak w tabeli 2)

Wyniki badań konsystencji zapraw przedstawiono na rysunku 3. Wynika z niego, że zastosowane dodatki mineralne zmniejszyły płynność zaprawy. Największy, 23\% spadek płynności odnotowano dla zaprawy z dodatkiem pyłu krzemionkowego. Stosując sam zeolit lub zamieniając połowę pyłu krzemionkowego na zeolit, uzyskano większy rozpływ. Spadek rozpływu dla tych dodatków wyniósł odpowiednio 19\% i 18\%.

Parametry wytrzymałościowe zapraw przedstawiono na rysunkach 4 i 5 . Wynika z nich, że stosowanie dodatków pucolanowych wpłynęło na obniżenie wytrzymałości wczesnej na zginanie i ściskanie. Największy spadek wytrzymałości odnotowano dla zapraw, w których zastosowano jedynie dodatek zeolitu. 


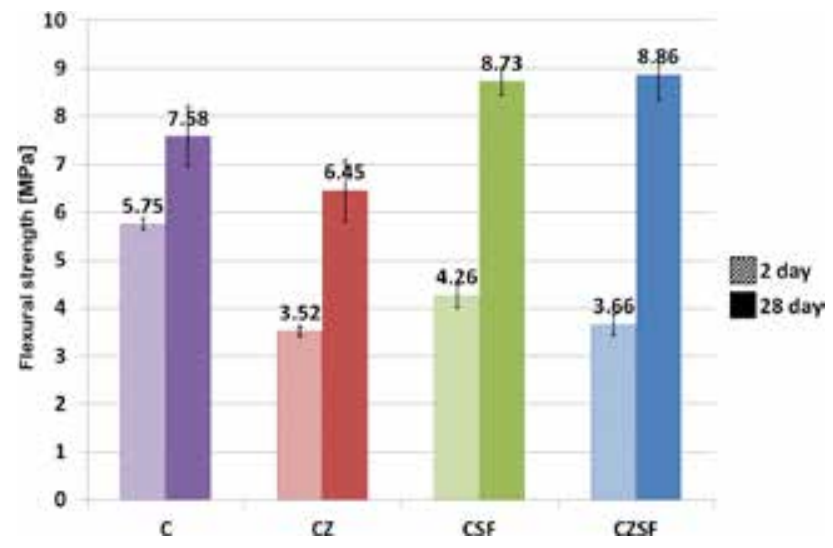

A significant increase in strength between 2 and 28 days of curing was observed in other mortars with pozzolanic admixtures (Fig. 6). This can be explained by the pozzolanic reaction $[8,9,18,21]$, which increased both flexural and compressive strengths of the mortars with additives, greater than that in reference mortars made with Portland cement. Silica fume used alone was confirmed to be a suitable component of high strength concrete $[3,4,10]$. The greatest increase in strength, between 2 and 28 days, however, was observed in the CZSF mortar containing the mixture made with zeolite and silica fume. Averaged strength parameters of this mortar slightly exceeded the parameters of mortar with silica fume binder. The second greatest increase in compressive strength was recorded for the $\mathrm{CZ}$ mortar. This increase, however, was not large enough to reach the strength of the mortar without mineral additives after 28 days. The silica fume mortar had only slightly lower increase in compressive strength. Due to the higher strength after 2 days, after 28 days this mortar had higher compressive strength than mortar $\mathrm{C}$. The silica fume mortar showed also a significant increase in flexural strength.

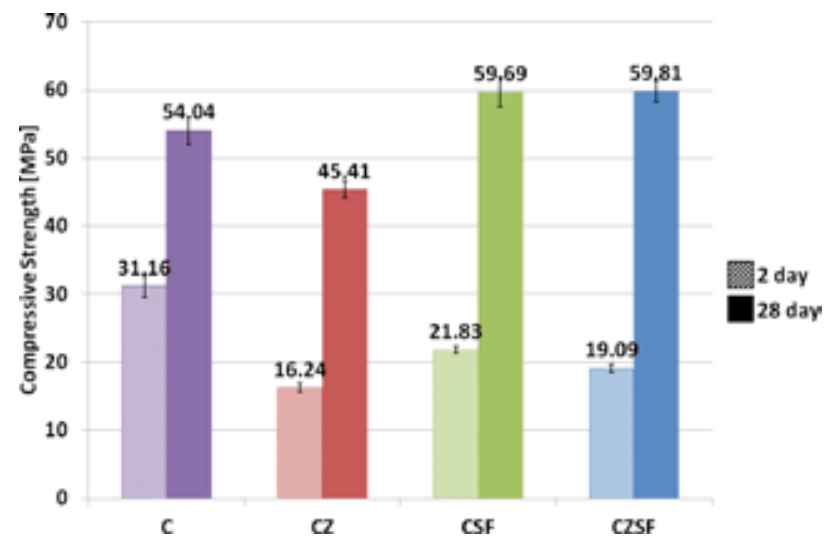

Higher flexural and compressive strengths of the mortar with silica fume compared to those of
Fig. 4. Flexural strength of mortars (notation as in Table 2) Fig. 4. Wytrzymatość zapraw na zginanie (oznaczenia próbek jak w tabeli 2)

Wyniki badań przeprowadzonych po 28 dniach również są najmniej korzystne dla zaprawy z tym spoiwem.

$\mathrm{W}$ pozostałych zaprawach $\mathrm{z}$ dodatkami pucolanowymi stwierdzono znaczący przyrost wytrzymałości między 2 a 28 dniem dojrzewania (rys. 6), co może być tłumaczone reakcją pucolanową $[8,9,18,21]$. Reakcja ta doprowadziła do tego, że zaprawy z dodatkami miały zarówno wytrzymałość na zginanie, jak i ściskanie większą niż zaprawy kontrolne na cemencie portlandzkim.

W przypadku zastosowania wyłącznie pyłu krzemionkowego, potwierdza ono jego przydatność jako składnika betonów o wysokiej wytrzymałości $[3,4$, 10]. Największym przyrostem wytrzymałości, między 2 a 28 dniem, odznacza się jednak zaprawa CZSF z mieszanką zeolitu i pyłu krzemionkowego. Uśrednione parametry wytrzymałościowe tej zaprawy przewyższyły nieznacznie również parametry zaprawy na spoiwie z dodatkiem pyłu krzemionkowego. Drugim co do wielkości przyrostem wytrzymałości na ściskanie cechowała się zaprawa CZ z dodatkiem zeolitu. Przyrost ten jednak nie był na tyle duży, by po 28 dniach osiągnąć wytrzymałość zaprawy bez dodatków mineralnych. Niewiele mniejszym przyrostem wytrzymałości na ściskanie cechowała się zaprawa $\mathrm{z}$ dodatkiem pyłu krzemionkowego. Jednakże, na skutek wyższej wytrzymałości po 2 dniach, po 28 dniach ta zaprawa miała wyższą wytrzymałość na ściskanie niż zaprawa C. Zaprawa z pyłem krzemionkowym cechowała się też znacznym przyrostem wytrzymałości na zginanie.

Fig. 5. Compressive strength of mortars (notation as in Table 2)

Fig. 5. Wytrzymatość zapraw na ściskanie (oznaczenia próbek jak w tabeli 2)

Wyższe wytrzymałości na ściskanie i zginanie zaprawy z pyłem krzemionkowym od zaprawy z zeoli- 
the mortar with zeolite can be explained by higher chemical activity of silica $[3,5,6,24]$. Silica fume alone may be responsible for the high strength of the mixture with both zeolite and silica fume (10\%), but a considerable strength increase between days 2 and 28 remains unexplained. The high strength of these mortars can also be related to the uniform distribution of pozzolan particles in the mixture, which additionally seals the mortar microstructure $[3,4]$. Another factor may be the spread in time of pozzolanic processes, when silica fume reacts faster and zeolite react slower, as demonstrated by the results of calorimeter tests.

High strength of mortars is also correlated with an adequate consistency [10]. More flowable consistency contributes to easier mortar densification and air pore removal. The presented results indicate that the mortar containing a mixture of zeolite and silica fume also had the highest flow of all mortars being analysed.

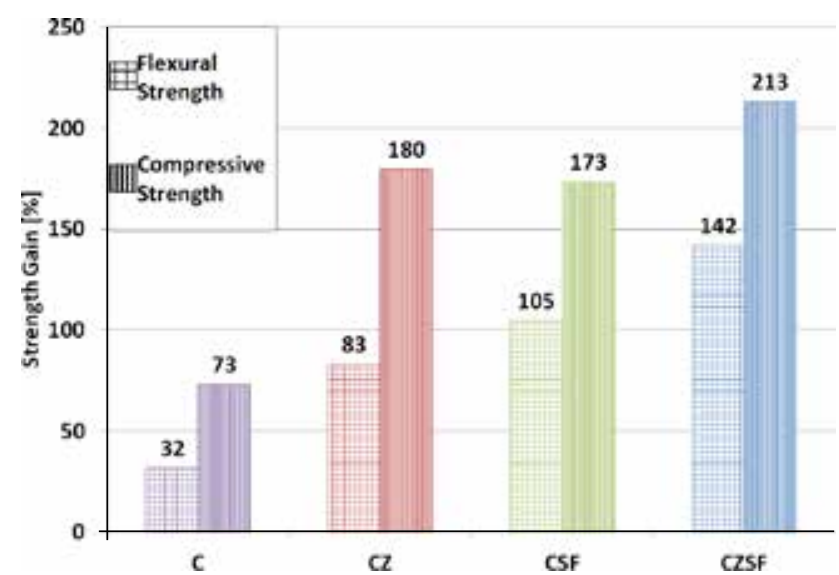

\section{CONCLUSIONS}

The following conclusions summarize the findings of the tests:

1. A blend of zeolite and silica fume improves the parameters of the cement paste compared to the effects of the two materials used individually. Replacement of $20 \%$ cement by weight by the zeolite-silica fume mixture added at the 1:1 ratio provides the mortar with consistency similar to that when $20 \%$ zeolite is used, but with the strength of a $20 \%$ silica fume mortar. Addition of zeolite-silica fume blend will improve the strength of the mortar and decrease its flow compared to the mortar with silica fume used alone.

2. The effect of the zeolite-silica fume mixture on the consistency and flexural and compressive strength tem można tłumaczyć większą aktywnością chemiczną amorficznej krzemionki [3, 5, 6, 24]. Za wysoką wytrzymałość zaprawy z mieszanką zeolitu i pyłu krzemionkowego mógłby odpowiadać sam pył, którego zwykle stosuje się w ilości do $10 \%$, ale nie tłumaczy to znacznego przyrostu wytrzymałości między 2 i 28 dniem.

Wysoka wytrzymałość tych zapraw może być też związana $\mathrm{z}$ równomierniejszym rozłożeniem ziaren pucolan w mieszance, przez co lepiej mogą doszczelniać mikrostrukturę zaprawy [3, 4]. Korzystne może być też rozłożenie w czasie procesów pucolanowych, kiedy to szybciej przereagowuje pył krzemionkowy, a wolniej zeolit. Świadczą o tym wyniki badań kalorymetrycznych.

Wysoka wytrzymałość zapraw powiązana jest również z odpowiednią konsystencją [10]. Bardziej płynna konsystencja przyczynia się do łatwiejszego zagęszczania zaprawy i usuwania porów powietrznych. Na podstawie przedstawionych wyników można stwierdzić, że największą płynnością spośród zapraw zawierających dodatki pucolanowe cechowała się również zaprawa z mieszanką zeolitu i pyłu krzemionkowego.

Fig. 6. Strength gain between 2 and 28 day (notation as in Table 2)

Rys. 6. Przyrost wytrzymałości między 2 a 28 dniem (oznaczenia próbek zgodne z tabela 2)

\section{WNIOSKI}

Z przeprowadzonych badań można wyciągnąć następujące wnioski:

1. Stosowanie mieszanki zeolitu i pyłu krzemionkowego, zamiast każde $\mathrm{z}$ tych pucolan osobno, korzystnie wpływa na parametry zaprawy cementowej. Zastępując 20\% masy cementu przez mieszankę zeolitu naturalnego i pyłu krzemionkowego o stosunku 1:1, otrzymuje się zaprawę o konsystencji zbliżonej do konsystencji zaprawy $\mathrm{z}$ dodatkiem $20 \%$ zeolitu, ale o wytrzymałości zaprawy z $20 \%$ udziałem pyłu krzemionkowego. Tym samym, stosując taki dodatek, zwiększeniu ulega wytrzymałość zaprawy przy mniejszym spadku jej płynności w porównaniu do zaprawy z pyłem krzemionkowym.

2. Wpływ mieszanki zeolitu naturalnego i pyłu krzemionkowego na konsystencję oraz wytrzymałość 
of the mortar is not an averaged effect that either of the materials provides. Further studies are needed to have a better understanding of this phenomenon. The studies should also cover determining the long-term influence of the two admixtures on the strength of mortars, and their combined influence on the mortar properties when added at different ratios.

3. Partial replacement of silica fume by zeolite offers cost-related advantage due to limited availability and price of the silica fume [3, 4]. Lower flow reduction, compensated by the use of plasticizers and superplasticizers $[4,10,18,21]$, may contribute to the reduction in their use thus decreasing the mortar production costs. na zginanie i ściskanie zaprawy nie jest uśrednionym wpływem, jaki wywiera na nie każda $z$ tych pucolan z osobna. W celu wyjaśnienia tego zjawiska należy podjąć dalsze badania. Dalsze badania powinny też objąć swym zakresem, określenie długoterminowego wpływu zastosowanych dodatków mineralnych na wytrzymałość zapraw. Należy też przebadać wpływ na właściwości zaprawy łącznego dodatku zeolitu i pyłu krzemionkowego mieszanych $\mathrm{w}$ innych proporcjach.

3. Możliwość częściowego zastąpienia pyłu krzemionkowego przez zeolit, ze względu na ograniczoną dostępność i cenę pyłu, jest korzystna ekonomicznie [3, 4]. Mniejszy spadek płynności, niwelowany przez stosowanie plastyfikatorów i superplastyfikatorów [4, 10, 18, 21], przyczynić się może do ograniczenia ich zużycia, a przez to również do ograniczenia kosztów produkcji zaprawy.

\section{References}

[1] PN-EN 197-1:2012 Cement. Composition, specifications and conformity criteria for common cements.

[2] Pacheco-Torgal F., Jalali S., Labrincha J., John V.M., Eco-efficient concrete, Elsevier, 2013.

[3] Nocuń-Wczelik W., Pyt krzemionkowy - wtaściwości i zastosowanie w betonie, Stowarzyszenie Producentów Cementu, Kraków 2005.

[4] Kurdowski W., Chemia cementu i betonu, SPC, Kraków 2010.

[5] Tkaczewska E., Effect of size fraction and glass structure of siliceous fly ashes on fly ash cement hydration, Journal of Industrial and Engineering Chemistry 20/1 (2014), pp. 315-321.

[6] Tkaczewska E., Małolepszy J., The properties of glass in siliceous fly ash, Cement Wapno Beton 14 (2009), pp. 148-153.

[7] Jasiczak J., Mikołajczak P., Technologia betonu modyfikowanego domieszkami i dodatkami, Politechnika Poznańska, Poznań 2003.

[8] Kotwa A., Spychał E., Influence of mineral additives properties of concrete, Structure and Environment 8/2 (2016), pp. 15-20.

[9] Owsiak Z., The hydration of Portland cement with fly ash, Cement Wapno Beton 5/1 (2000), pp. 29-31.

[10] Jasiczak J., Wdowska A., Rudnicki T., Betony ultrawysokowartościowe - właściwości, technologie, zastosowanie, Polski Cement, Kraków 2008.

[11] Nocuń-Wczelik W., Nowak M., Kapeluszna E., Lightweight mortars with expanded perlite modified by admixtures, Structure and Environment 9/2 (2017), pp. 102-111.

[12] Owsiak Z., Wójcik A., The influence of co-combusted biomass-coal fly ash on limiting alkali-silica reaction, Structure and Environment 6/2 (2014), pp. 26-31.

[13] Mansour M.S., Abadlia M. T., Jauberthie R., Messaoudene I., Metakaolin as a pozzolan for high-performance mortar, Cement Wapno Beton 17/2 (2012), pp. 102-108.

[14] Małolepszy J., Pytel Z. Effect of Metakaolinite on Strength and Chemical Resistance of Cement Mortars, (in) Proc. of Fifth International Conference "Durability of Concrete, Vol I" Ed. by V.M. Malhotra, Spain, Barcelona 2000.

[15] Wala D., Rosiek G., The clay minerals as pozzolanic addition for water cements, Cement Wapno Beton 8/1 (2003), pp. 27-33.

[16] Pytel Z., Małolepszy J., Effects of parameters of thermal treatment on the pozzolanic properties of burnt kaolin clay, Cement Wapno Beton 4/3 (1999), pp. 80-83.

[17] Czapik P., Czechowicz M., Effects of natural zeolite particle size on the cement paste properties, Structure and Environment 9/3 (2017), pp. 180-190.

[18] Ahmadi B., Shekarchi M., Use of natural zeolite as a supplementary cementitious material, Cement and Concret Composites 32/2 (2010), pp. 134-141. 
[19] Vejmelková E., Keppert M., Ondráček M., Černý R., Effect of natural zeolite on the properties of high performance concrete, Cement Wapno Beton 18/3 (2013), pp. 150-159.

[20] Siemaszko-Lotkowska D., Gajewski R., Właściwości zeolitu w aspekcie zastosowania w betonie (2008), pp. 11011108.

[21] Małolepszy J., Grabowska E., Wpływ zeolitów na proces hydratacji spoiw mineralnych, Budownictwo i Architektura 12/3 (2013), pp. 185-192.

[22] Karakurt C., Topçu İ.B., Effect of blended cements produced with natural zeolite and industrial by-products on alkali-silica reaction on sulfate resistance of concrete, Construction and Building Materials 25/4 (2011), pp. 1789-1795.

[23] Czapik P., Aktywność zeolitu naturalnego w środowisku zaczynu cementowego, (in) Proc. of $14^{\text {th }}$ Conference of the Scientific Conference for Civil Engineering PhD Students „Wiedza i eksperymenty w budownictwie” Ed. by J. Bzówka, Politechnika Śląska, Gliwice 2014.

[24] Broekmans M.A.T.M., Structural properties of quartz and their potential role for ASR, Materials Characterization 53/2-4 (2004), pp. 129-140.

[25] Ciciszwili G.W., Zeolity naturalne, Wydawnictwo Naukowo-Techniczne, Warszawa 1990.

[26] Gil D.M., Golewski G.L., Wplyw dodatku pylu krzemionkowego (SF) i krzemionkowych popiotów lotnych (FA) na krytyczny wspótczynnik intensywności naprężeń betonu, Materiały Budowlane 1 (2017), pp. 48-49.

[27] Giergiczny Z., Cementy popiołowe z dodatkami pylu krzemionkowego, Cement Wapno Beton 1 (1995), pp. 17-22.

[28] Pieczonka J., Piestrzyński A., Parańko I., Geologia wybranych złóż surowców mineralnych Ukrainy, AGH, Kraków 2011.

[29] Barnat-Hunek D., Siddique R., Klimek B., Franus M., The use of zeolite, lightweight aggregate and boiler slag in restoration renders, Construction and Building Materials 142/1 (2017), pp. 162-174.

[30] PN-EN 1015-3:2000 Methods of test for mortar for masonry. Determination of consistence of fresh mortar (by flow table).

[31] PN-EN 196-1:2016-07 Methods of testing cement. Determination of strength.

[32] Zhang M.-H., Sisomphon K., Ng T.S., Sun D.J., Effect of superplasticizers on workability retention and initial setting time of cement pastes, Construction and Building Materials 24/9 (2010), pp. 1700-1707.

[33] Taylor H.F.W., Cement Chemistry, Academic Press, London 1990.

[34] Usherov-Marshak A.V.V., Ciak M.J., Isothermal calorimetry in the standard ASTM C1679-08, Cement Wapno Beton 15/2 (2010), pp. 108-110.

\section{Acknowledgments:}

This work was supported by Kielce University of Technology, Grant No. 02.0.05.00/2.01.01.02.0057 MNSC.BKTO.15.005

\section{Podziękowania:}

Praca była finansowana przez Politechnikę Świętokrzyska, grant nr 02.0.05.00/2.01.01.02.0057 MNSC.BKTO.15.005 